Gut, $1987,28,1128-1133$

\title{
Origin of gastrin liberated by gastrin releasing peptide in man
}

\author{
L LUNDELL, G LINDSTEDT, AND L OLBE \\ From the Departments of Surgery II and Clinical Chemistry, Sahlgren's Hospital, University of Gothenburg, \\ Gothenburg, Sweden
}

SUMMARY Gastrin release induced by gastrin releasing peptide (GRP) in man has been studied in patients before and after complete resection of the antrum and duodenal bulb, as well as after pancreaticoduodenectomy according to Whipple. Studies in healthy subjects showed that 400 $\mathrm{pmol} / \mathrm{kg}$ an hour of GRP induced a maximal release of gastrin. Infusion of this dose of GRP after a complete resection of the antrum and duodenal bulb induced a small, but significant increase in gastrin concentrations. After pancreaticoduodenectomy, however, GRP infusion had no effect on serum gastrin concentrations. In patients previously subjected to an incomplete antrectomy, GRP infusion was followed by a gastrin response considerably higher than after a complete antrectomy. Our results would suggest that GRP is capable of releasing gastrin predominantly from the antrum and the duodenal bulb, but also a small amount of gastrin from the remaining part of the duodenum. Gastrin releasing peptide infusion and determination of gastrin release may be of clinical significance in showing remaining significant gastrin pools in patients with recurrent ulceration after previous gastric resections.

The tetradecapeptide bombesin originally isolated from the frog skin has been found to have counterparts in mammalian stomach and intestine.' Bombesin like immunoreactive material has been found in high concentrations in the human gastric mucosa as well as in the muscle layers of the stomach both in the fundus and in the antrum. ${ }^{23}$ Bombesin is a potent stimulant for gastrin release in all species studied and has been shown to induce a dose dependent gastrin release also in man. ${ }^{+5}$ From the porcine non-antral gastric tissue a 27 -aminoacid peptide hormone with a striking sequence homology with the frog's skin peptide bombesin has been isolated and termed gastrin releasing peptide. ${ }^{6}$ Gastrin releasing peptide (GRP) has recently been shown to be equipotent with bombesin in raising plasma concentrations of some gastroenteropancreatic hormones. ${ }^{78}$ Gastrin releasing peptide has been suggested to play a role in the neuroregulation of gastrin secretion from the antrum but the peptide seems to produce a wide variety of

Address for correspondence: Lars Lundell, MD. PhD. Department of Surgery II. Sahlgren`s Hospital, S-41345 Gothenburg. Sweden.

Received for publication 12 February 1987 biological effects in mammals including stimulation of gastric acid secretion (probably secondary to the gastrin release), pancreatic enzyme secretion, gall bladder and intestinal smooth muscle contraction and release of several gastrointestinal regulatory peptides..$^{4-12}$ Gastrin releasing peptide administration in man is followed by substantial gastrin release. There are, however, divergent results as to the release of other gastrointestinal peptides..$^{1.214}$

It has been suggested that bombesin and consequently GRP as well might be of clinical usefulness to reveal remaining gastrin sources in patients with recurrent peptic ulcerations after previous gastric resections. Results have been presented indicating both an antral and extra antral release of gastrin by bombesin. ${ }^{15-18}$ The aim of the present study was to investigate the dose response relationship between infused dose of GRP and the amount of gastrin released and also to investigate the origin of gastrin released by GRP by carrying out studies on patients before and after histologically complete antrectomy and duodenal bulb resection as well as after a pancreaticoduodenectomy according to Whipple. 


\section{Methods}

\section{PATIENTS}

Studies were carried out on six healthy volunteers (mean age 56 years, range $36-68$ ) and eight patients (mean age 46 years, range 30-63) before and at least three months after a histologically complete antrumbulb resection, six of whom also had a selective gastric vagotomy. The preoperative investigation was carried out after any ulcer drug treatment had been postponed for at least 48 hours. All eight patients had a gastroduodenostomy according to Billroth I. The operative specimens were subjected to routine histopathological investigation with haematoxylin and eosin staining. Six patients (mean age 67 years, range 61-75) were investigated six months after a pancreaticoduodenectomy according to Whipple because of pancreatic carcinoma. At the time of investigation no sign of remaining or recurrent tumour growth was apparent. Six patients (mean age 59 years, range 49-70) were also investigated at different time intervals after a histologically incomplete antrectomy. All subjects gave their informed consent to take part in the investigation, which was approved by the local ethical committee. In four subjects (mean age 49 years, range 42-67), two healthy volunteers and two patients previously operated on with proximal gastric vagotomy, one test was carried out without nasogastric intubation and one test at least three weeks afterwards were carried out by perfusion of the stomach with a buffer solution (Sörensens buffer) in order to obtain a stable $\mathrm{pH}$ of 7 in the gastric lumen (for technical details see ${ }^{19}$ ).

Each subject was studied in the morning after an overnight fast. If not otherwise stated no nasogastric tube was inserted. A cannula was inserted into an arm vein for infusion of GRP and another in a vein in the other arm for blood sampling.

The GRP used was synthetic preparation of the porcine peptide (Cambridge Research Biochemical Ltd, UK). For infusion, the peptide was dissolved in sterile aqueous $0.15 \mathrm{~mol} / \mathrm{l}$ sodium chloride solution containing $5 \mathrm{~g} / \mathrm{l}$ of human albumin, the latter to reduce absorption of the peptide to the plastic syringe and tubing of the infusion equipment.

For gastrin determination, $10 \mathrm{ml}$ of blood was drawn at 15 minute intervals into glass tubes without anticoagulant or other additive and, after centrifugation serum was removed and stored at $-20^{\circ} \mathrm{C}$ until time of assay. Gastrin was determined ${ }^{20}$ using a double antibody polyethylene glycol assisted radioimmunoassay (Diagnostic Products Corporation, Los Angeles, California, USA) using human nonsulphated gastrin-17 for calibration. The method is standardised against Research Standard A (68-439, synthetic human non-sulphated gastrin-17). One

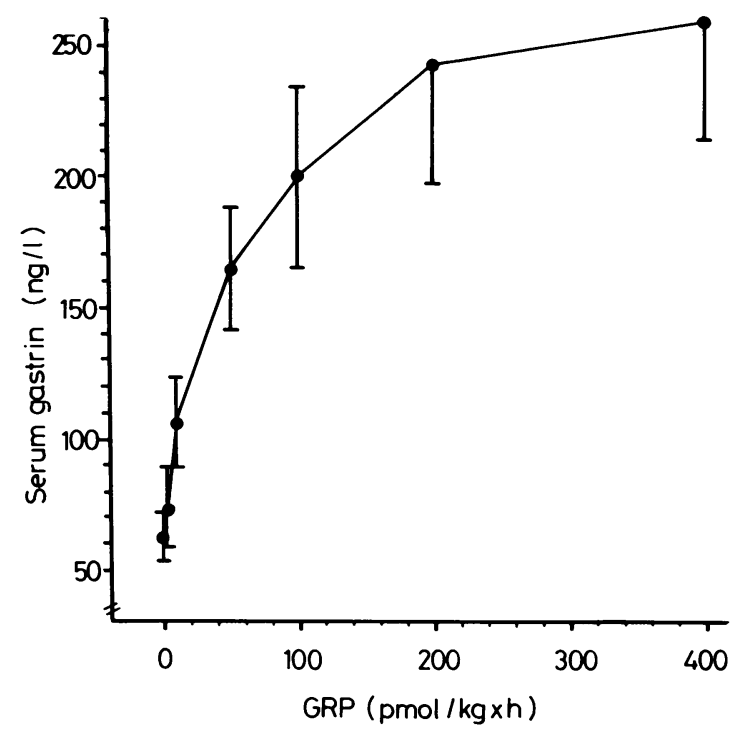

Fig. 1 Gastrin response to stepwise increasing doses of $G R P$ in healthy volunteers. Mean and SE are given.

nanogram of the calibrator corresponds to $0.95 \mathrm{mU}$ and $0.48 \mathrm{pmol}$. The stated cross-reactivity with nonsulphated gastrin-34 (an $80 \%$ pure preparation) $62-73 \%$ depending on the concentration - that is, the assay does not discriminate between the major species of serum gastrin. The precision of the assays during the present study period was similar to that reported previously. ${ }^{20}$ For cross-reactivity data with cholecystokinin see the foot note. ${ }^{*}$

In studying the dose response relationship between infused dose of GRP and gastrin release, each dose of GRP was infused for 45 minutes. The gastrin response to each dose of GRP was calculated as the mean of the two last 15 minute samples. The dose of GRP was stepwise increased.

Statistical evaluation of the data was carried out by application of the Student's $t$ test.

\section{Results}

DOSE RESPONSE RELATIONSHIP

The mean basal serum gastrin concentration in the six healthy volunteers was 63 (SE 9.2) ng/l. On infusing GRP in a dose of $10 \mathrm{pmol} / \mathrm{kg} / \mathrm{h}$, the serum gastrin increased to $106 \mathrm{ng} / \mathrm{l}$. A dose response relationship was obtained between infused dose of GRP and gastrin release (Fig. 1). A maximal gastrin releasing

*The manufacturer gives the following cross-reactivity data for cholecystokinin CCK $27-33$ added $1 \mu \mathrm{g} / 1-9 \cdot 7 \%, \mathrm{CCK}_{32} 33$ added $1 \mu \mathrm{g} / \mathrm{l}-0.7 \%, \mathrm{CCK}_{25}-33$ (non sulphated) added $1 \mu \mathrm{g} / 1-29 \cdot 4 \%$ and $\mathrm{CCK}_{26-33}$ (sulphated) added $1 \mu \mathrm{g} / \mathrm{l}$ gives a per cent cross-reactivity of $19 \cdot 4$ 


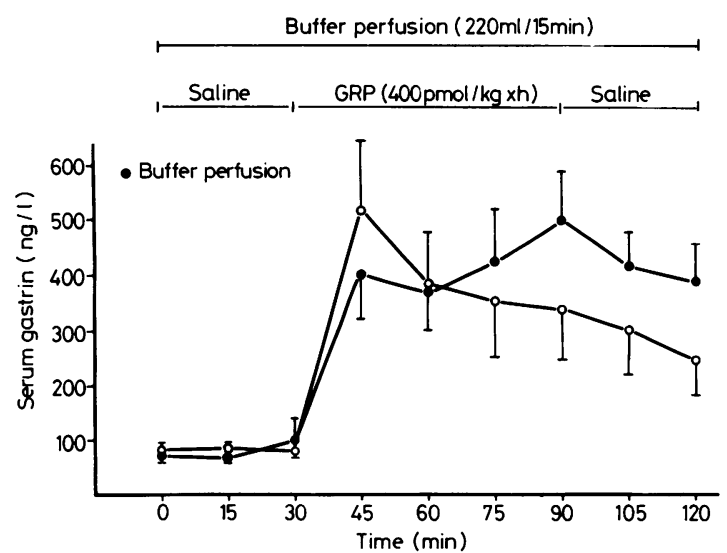

Fig. 2 Gastrin response to GRP infusion in four patients with or without buffer perfusion of the gastric lumen (see Methods). Mean and $S E$ are given.

effect seemed to follow infusion of 400 pmol of $\mathrm{GRP} / \mathrm{kg} / \mathrm{h}$.

\section{INFLUENCE OF LUMINAL PH ON GASTRIN} RELEASE

In four subjects, a GRP infusion $(400 \mathrm{pmol} / \mathrm{kg} / \mathrm{h})$ was done either without nasogastric intubation or during perfusion of the stomach with Sörensens buffer solution. The initial gastrin response did not differ between the two investigations (Fig. 2), but the response to GRP infusion during buffer perfusion seemed to be more prolonged than without nasogastric intubation.

\section{GASTRIN RESPONSE BEFORE AND AFTER \\ ANTRECTOMY}

In eight patients with pyloric-prepyloric ulcer or gastric ulcer disease and admitted for surgical treatment, a test with infusion of GRP in a dose of 400 $\mathrm{pmol} / \mathrm{kg} / \mathrm{h}$ for one hour was carried out. Preoperatively, the basal serum gastrin concentration was 65 $\mathrm{ng} / \mathrm{l}$ and on GRP infusion a rapid gastrin peak of 319 (SE 56) $\mathrm{ng} / \mathrm{l}$ was seen already after 15 minutes of GRP infusion (Fig. 3). Serum gastrin concentrations thereafter levelled off at a plateau of about $250 \mathrm{ng} / \mathrm{l}$. A slow decline in serum gastrin concentrations was seen on subsequent saline infusion. After a histologically complete antrectomy, including also a resection of the duodenal bulb, the basal gastrin concentration was reduced to about $40 \mathrm{ng} / \mathrm{l}$. On GRP infusion there was, however, a small but significant increase $(p<0.05)$ in gastrin concentration with a gastrin peak during the first 15 minute period of 71 (SE 11) $\mathrm{ng} / \mathrm{l}$. During the GRP infusion the gastrin concentration plateaued at $55 \mathrm{ng} / \mathrm{l}$ and a slight decrease was seen on subsequent saline infusion.

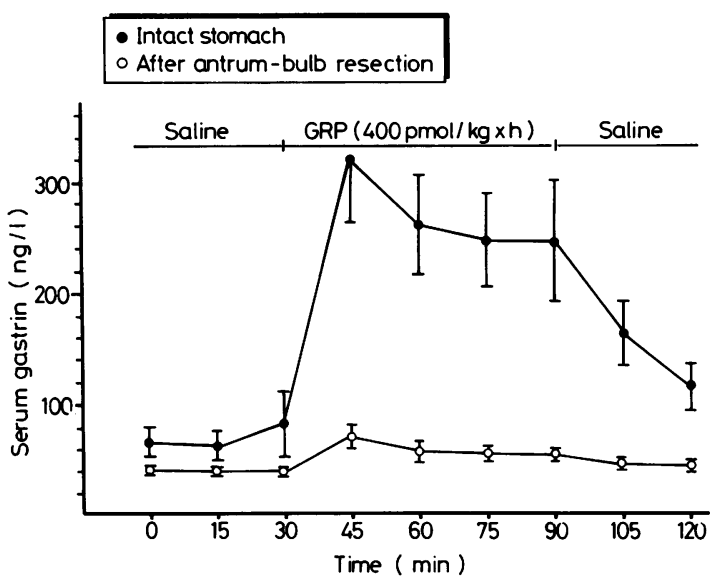

Fig. 3 Gastrin response to GRP infusion before and after complete resection of the antrum and duodenal bulb. Mean and $S E$ are given.

\section{GASTRIN RESPONSE AFTER}

\section{PANCREATICODUODENECTOMY}

Investigations on six patients carried out after pancreaticoduodenectomy revealed no increase in serum gastrin during infusion of $400 \mathrm{pmol} / \mathrm{kg} / \mathrm{h}$ of GRP (Fig. 4).

\section{INCOMPLETE ANTRECTOMY}

Six patients were investigated because of recurrent ulcers after a previous gastric resection and were found either on a retrospective analysis of the operative specimen to have had an incomplete antrectomy or revealed at gastroscopic biopsies to have remaining G-cells in the prestomal area by immunostaining of the biopsy material. The gastrin response to GRP differed considerably among patients but as seen in Figure 5, the gastrin response was considerably higher than after a complete antrectomy. Three of these patients have been submitted to further surgery, including reresection of the stomach and/or the duodenal bulb. In these patients the basal gastrin

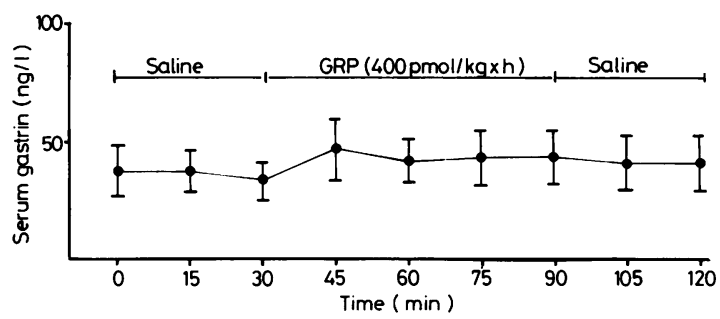

Fig. 4 Gastrin response to GRP infusion in patients previously operated on with a pancreatico-duodenectomy according to Whipple. Mean and SE are given. 


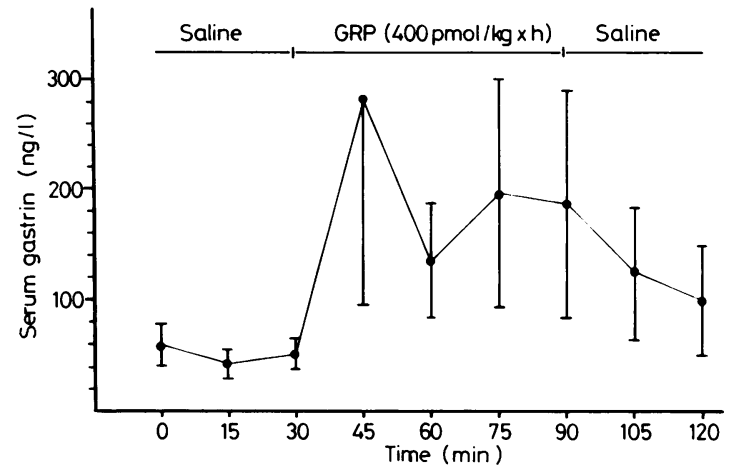

Fig. 5 Gastrin response to GRP infusion in patients previously operated on with a histologically incomplete antrectomy. Mean and $S E$ are given.

did not differ from the pre- to the postoperative investigation. The peak gastrin concentration during GRP was, however, reduced from $113 \mathrm{ng} / \mathrm{l}$ to $86 \mathrm{ng} / \mathrm{l}$ after the reoperation.

\section{Discussion}

A test for gastrin secretory capacity might be clinically useful for instance in revealing the remaining antrum which may be of pathophysiological significance in patients with recurrent ulceration after previous gastric resection. ${ }^{1621}$ The major circulating molecular species of gastrin with 17- and 34-amino acids, respectively, behave differently with respect to elimination from the blood stream, $\mathrm{t}_{1 / 2}$ being five to six minutes for gastrin-17 and 40 minutes for gastrin-34..$^{22}$ Clinical gastrin assays should be nonselective with respect to the molecular species of gastrin ${ }^{2023}$ but different assays may differ in terms of cross-reactivity depending on antiserum and assay conditions. We used a clinically validated nonselective gastrin assay.

Our results from study on the dose response relationship indicate, that the prolonged infusion of $400 \mathrm{pmol}$ of $\mathrm{GRP} / \mathrm{kg} / \mathrm{h}$ provided maximal stimulus for gastrin release assessed from serum gastrin measurements. Although a single bolus of GRP might be more convenient for clinical use, we attempted to avoid problems related to possible differences in elimination and/or inactivation of GRP between patients and also some problems related to the assessment of secretory response of peptides with rapid elimination rates when bolus injections are used. Using the dose of $400 \mathrm{pmol}$ of GRP/kg we found the same gastrin response irrespective of whether the gastric contents were acid or neutral, indicating that the gastrin release induced by this dose of GRP is not inhibited by antral acidification and suggesting that there is no need for nasogastric intubation in the clinical GRP test.

Previous studies have alleged that bombesin was unable to stimulate gastrin release in man when antral mucosa was absent. ${ }^{15}$ Recent results have, however, been presented in man indicating an extragastric gastrin release induced by bombesin. ${ }^{18}$ In the present study, we found a small but significant gastrin release induced by GRP in patients operated on with a histologically complete antrectomy including also the duodenal bulb known to contain significant amounts of gastrin. ${ }^{24}{ }^{25}$ Gastrin releasing peptide was without effect on serum concentration of gastrin after a pancreaticoduodenectomy according to Whipple, a surgical procedure also including resection of the head of the pancreas. Gastrin cells are very rare in the head of the pancreas - with the exception of patients with the Zollinger-Ellison syndrome, but are present in the descending part of the duodenum although these cells are more sparsely distributed. ${ }^{25}$ Our results indicate that gastrin releasing peptide, in the dose presently used, is capable of releasing gastrin from the descending part of the duodenum. In man more than $90 \%$ of the antral gastrin immunoreactivity is gastrin-17, while in the duodenum $35-50 \%$ of the gastrin immunoreactivity is because of gastrin-34..$^{26}{ }^{27}$ Further studies are warranted to elucidate whether the gastrin response to GRP after histologically complete antrectomy is due to a rise only in gastrin-34 concentration.

Bombesin as well as GRP are potent stimulants for the release of cholecystokinin. ${ }^{132 \times}$ The assay presently used for serum gastrin determination is encumbered with a low cross-reactivity with cholecystokinin, although it cannot be completely ruled out that a small part of the short lasting gastrin response to GRP after antrum-bulb resection might be caused by cholecystokinin release. It should be pointed out, however, that the cholecystokinin response to comparable doses of bombesin and GRP has a completely different time course also after a gastric resection. ${ }^{132 x}$ Our observations on patients previously operated on with an incomplete antrectomy illustrate that GRP infusion, as presently applied, may be of clinical use to reveal incomplete antrectomy. This test has, however, to be applied to a larger number of patients to allow a more firm conclusion.

The mechanism(s) for gastrin release from extraantral pools is incompletely known. Antrectomy is known to be followed by a decrease but not an elimination of basal gastrin concentration. It has previously been shown that truncal vagotomy may increase basal gastrin concentrations after antrectomy ${ }^{29.31}$ indicating a vagal inhibitory influence on extra-antral gastrin release under basal conditions. Obviously, GRP infusion may be an interest- 
ing tool for investigation of mechanisms for the release of extra-antral gastrin when applied to patients previously submitted to a complete antrectomy.

It has recently been shown, that in patients operated on with a histologically complete antrectomy and a Billroth I reconstruction because of juxtapyloric ulcer disease, the recurrence rate was unacceptably high - about $20 \%$ - during a five year follow up period. ${ }^{31}$ An interesting observation was that patients who subsequently developed a recurrency, restored their acid secretory capacity to almost the preoperative level. The interpretation of this observation is open to question but extraantral gastrin pools taking over the trophic effect of antral gastrin and successively restoring the acid secretory capacity in patients presenting a recurrent ulcer, must be considered. After antrectomy in dogs, there seems to be a compensatory gastrin production in the proximal duodenum that is more pronounced after gastroduodenostomy than after gastrojejunostomy. ${ }^{32} 33$

This study was supported by a grant from the Swedish Medical Research Council (17 X-760).

\section{References}

1 Walsh JH, Holmquist AL. Radioimmunoassay of bombesin peptides. Identification of bombesin-like immunoreactivity in vertebrate gut extracts. Gastroenterology 1976; 70: 948.

2 Polak JN, Bloom SR, Hobbs S, et al. Distribution of bombesin-like peptide in human gastrointestinal tract. Lancet 1976; i: 1109-10.

3 Price J, Penman E, Wass JAH, Rees LH. Bombesin-like immunoreactivity in human gastrointestinal tract. Regul Peptides 1984; 9: 1-10.

4 Hirshowitz BI, Tim LO, Hellman CA, Molina E. Bombesin and G-17 dose responses in duodenal ulcer and controls. Dig Dis Sci 1985; 30: 1092-103.

5 Varner AA, Modlin IM, Walsh JH. High potency of bombesin for stimulation of human gastrin release and gastric acid secretion. Regul Peptides 1981; 1: 289-96.

6 McDonald TJ, Jörnvall H, Nilsson G, et al. Characterisation of a gastrin releasing peptide from porcine nonantral gastric tissue. Biochem Biophys Res Commun 1979; 90: 229-33.

7 McDonald TJ, Ghati MS, Bloom SR, et al. Dose response comparisons of canine plasma gastroenteropancreatic hormone responses to bombesin and the porcine gastrin-releasing peptide. Regul Peptides 1983; 5: 125-37.

8 Lambert JR, Hansky J, Soveny C, Hunt T. Comparative effects of bombesin and porcine gastrin-releasing peptide in the dog. Dig Dis Sci 1984; 29: 1036-40.

9 DuVal JW, Saffouri B, Weir GC, et al. Stimulation of gastrin and somatostatin secretion from the isolated rat stomach by bombesin. Am J Physiol 1981; 241: G242-7.
10 Inoue KD, McKay HY, Rayford TL. Effect of synthetic porcine gastrinreleasing peptide on plasma levels of immunoreactive cholecystokinin, pancreatic polypeptide and gastrin in dogs. Peptides $1983 ; 4: 153-7$.

11 Martindale R, Kauffman GL, Levin S, Walsh JH, Yamada $T$. Differential regulation of gastrin and somatostatin secretion from isolated perfused rat stomachs. Gastroenterology 1982; 83: 240-4.

12 Maghimzadeh E, Ekman R, Håkanson R, Yanaihara N, Sundler F. Neuronal gastrin-releasing peptide in the mammalian gut and pancreas. Neuroscience 1983; 10: 553-63.

13 Wood SM, Jung RT, Webster JD, et al. The effect of the mammalian neuropeptide, gastrin-releasing peptide (GRP), on gastrointestinal and pancreatic hormone secretion in man. Clin Sci 1983; 65: 365-71.

14 Knigge U, Holst J, Knutsen S, et al. Gastrin-releasing peptide: pharmacokinetics and effects on gastroenteropancreatic hormones and gastric secretion in normal man. J Clin Endocrinol Metab 1984; 59: 310-15.

15 Basso $\mathrm{N}$, Lezoche $\mathrm{E}$, Materia $\mathrm{A}$, et al. Effect on bombesin on extra-gastric gastrin in man. Dig Dis 1975; 20: $923-7$.

16 Basso N, Lezoche E, Giri S, et al. Acid and gastrin levels after bombesin and calcium infusion in patients with incomplete antrectomy. Dig Dis 1977; 22: 1258.

17 Speranza V, Basso N, Lezoche E. Effects of bombesin and calcium on serum gastrin levels in patients with retained or excluded antral mucosa. Adv Exp Med Biol 1978; 106: 319-24.

18 Annibale B, Korleto W, Severi C, et al. Evidence that bombesin releases extra-gastric gastrin in man. Regul Peptides 1985; 11 : 43-9.

19 Bergegårdh S, Knutson U, Olbe L. The effect of intragastric neutralization on the gastric acid response to antral distension in man. Scand J Gastroenterol 1975; 10: 625-31.

20 Lindstedt G, Olbe L, Kilander AF, et al. Analytical and clinical evaluation of a radioimmunoassay for gastrin. Clin Chem 1985; 31: 76-82.

21 Speranza V, Basso N, Lezoche E, et al. Management and long-term results in patients with $2 / 3$ gastrectomy and stomal ulcer. Am J Surg 1981; 141: 105-9.

22 Walsh JH, Isenberg JI, Ansfield J, Maxwell W. Clearance and acid stimulating action of human big and little gastrins in duodenal ulcer subjects. J Clin Invest 1976; 57: $1125-31$.

23 Rehfeld JF, Andersen BN, Petersen SB, et al. Misuse of gastrin radioimmunoassay kits. Lancet 1983; ii: 338 .

24 Buffa R, Solcia E, Go VLW. Immunohistochemical identification of the cholecystokinin cell in the intestinal mucosa. Gastroenterology 1976; 70: 528-32.

25 Ciacosa A, Crivelli O, Cheli R. G-cell distribution in normal duodenal mucosa. Scand J Gastroenterol 1979; 54: suppl 14: 14-7.

26 Malmström J, Stadil F, Rehfeld JF. Gastrin in tissue: concentration and component pattern in gastric, duodenal and jejunal mucosa of normal human subjects and patients with duodenal ulcer. Gastroenterology 1976; 70: 697-703.

27 Creutzfeldt W, Arnold L, Creutzfeldt C, Track NS. Mucosal gastrin concentration, molecular forms of 
gastrin, number and ultrastructure of G-cells in patients with duodenal ulcer. Gut 1976; 17: 745-54.

28 Jansen JBMJ, Lamers CBHW. Effect of bombesin on plasma cholecystokinin in normal persons and gastrectomized patients measured by sequence-specific radioimmunoassays. Surgery 1984; 96: 55-60.

29 Korman MG, Soveny C, Hansky J. Extra-gastric gastrin. Gut 1972; 13: 346-8.

30 Eckhardt VF, Grace ND, Osborne MP, Fisher JE. Lower oesophageal sphincter pressure and serum gastrin levels after mapped antrectomy. Arch Intern Med 1978; 138: 243-5.
31 Rehnberg O. Antrectomy and gastroduodenostomy with or without vagotomy in peptic ulcer disease. A prospective study with a 5-year follow up. Acta Chir Scand 1983: suppl 515.

32 Brodin $\mathrm{K}$, Nilsson $\mathrm{G}$. Increase in duodenal tissue gastrin in dogs following antrectomy with gastroduodenostomy and after total gastrectomy with oesophagoduodenostomy. Acta Physiol Scand 1982; 116: 113-20.

33 Brodin $K$, Nilsson G. Gastrin in duodenal and jejunal tissue and in plasma following antrectomy with gastrojejunostomy. Acta Physiol Scand 1982; 116: $153-8$. 